increasing magnetic field strengths. Neurosurgeons should try to remember this risk when using such clips and should use non-ferromagnetic clips whenever possible. At present we exclude from magnetic resonance imaging any patient who is known to have any aneurysm clip since as well as the risk of detachment the image is severely degraded.

We thank the Department of Health and Social Security and Picker International for their continuing support. We would also like to thank Downs Surgical Ltd for making the microsurgical slips available. These findings were initially presented by $\mathrm{Mr} \mathrm{J}$ Firth at the 7th International Congress of the International Microsurgical Society, September 1982.

DM KEAN BS WORTHINGTON JL FIRTH

RC HAWKES

Department of Radiology

Queens Medical Centre

Nottingham, NG7 2UH UK

\section{Rapid enlargement of non-functioning pituitary tumour following withdrawal of bromocriptine}

Sir: Bromocriptine, an ergot derivative with dopamine receptor agonist properties, has been shown to reduce the size of prolactin secreting pituitary tumours. ${ }^{1}$ Recent work has demonstrated involution of adenomatous prolactin cells with tumour shrinkage occurring within three weeks of commencing bromocriptine. ${ }^{2}$ The effect of bromocriptine upon other pituitary adenomas is uncertain. Occasional reports have suggested that a reduction in tumour size may occur in non-functioning ${ }^{134}$ and growth hormone secreting tumours. ${ }^{5}$ We report a patient with a non-functioning chromophobe adenoma whose visual acuity deteriorated rapidly following withdrawal of bromocriptine.

The patient presented in October 1981 with visual impairment and lethargy. Bilateral optic atrophy was present with a bitemporal hemianopia and visual acuities of $6 / 24$ bilaterally. Chiasmal compression was suspected and pituitary fossa tomograms and CT scan confirmed the presence of a pituitary macro-adenoma with suprasellar extension. Hypopituitarism was confirmed biochemically and serial prolactins in the range $530-630 \mathrm{mU} / 1$ (normal range for females less than $300 \mathrm{mU} / \mathrm{l}$ ) were too low to represent a prolactinoma. The patient refused surgery and was com- menced on replacement therapy with hydrocortisone $10 \mathrm{mg}$ b.d. and thyroxine $0 \cdot 1$ mg a day. Bromocriptine $2.5 \mathrm{mg}$ eighthourly was added when an outpatient serum prolactin of $890 \mathrm{mU} / \mathrm{l}$ was reported three months later. During the next two years her visual acuity and field defect remained unchanged as did pituitary fossa tomography. Her serum prolactin was persistently less than $100 \mathrm{mU} / \mathrm{l}$. She was readmitted in September 1983 with a chest infection. As she also complained of indigestion with reflux and was found to have a hiatus hernia with an iron deficiency anaemia, her bromocriptine was stopped. At outpatient review six weeks later she complained of marked visual loss and her acuities had deteriorated to $5 / 60$ in both eyes with further field restriction. CT scan revealed enlargement of the tumour with marked suprasellar extension but no evidence of pituitary apoplexy. Her serum prolactin was $430 \mathrm{mU} / \mathrm{l}$. Subfrontal decompression was carried out but the patient died after operation from a myocardial infarction. Histology revealed a chromophobe adenoma with no evidence of pituitary infarction. Stains for prolactin using the immunoperoxidase technique were negative.

We feel that the rapid deterioration in vision within six weeks of stopping bromocriptine was due to tumour enlargement, suggesting that bromocriptine may also have a suppressive action on some non-functioning pituitary tumours. The time course of enlargement was of the same scale noted by Barrow et al who observed prolactinoma re-expansion within 7-14 days of stopping bromocriptine in two patients. ${ }^{2}$ When bromocriptine is discontinued in patients with pituitary macroadenomas, visual fields and tumour size should be monitored even if the tumour is non-functioning.

JDA CLARK
T WHEATLEY
OM EDWARDS
Hills Road,
Hildenbrooke's Hospital,
Cambridge CB2 2QQ, UK
Scanlon MF, Hall R, Hall K.
bromocriptine on pituitary
Br Med J 1979;i:700-3.
Tindall GT, Kovacs K, Thorner
th E, Hoffman JC. Clinical and
leffects of bromocriptine on
secreting and other pituitary
Neurosurg 1984;60:1-7.

JDA CLARK WHEATLEY

$$
\text { prol }
$$
cell autoantibodies. A control group of normal 80 year olds and patients with Parkinson's disease had much lower rates of positive reactions (three of 21 and two of 40 respectively). Three out of 10 patients with multi-infarct dementia had prolactin cell autoantibodies. These antibodies were first described in patients with autoimmune polyendocrine disease ${ }^{7}$ and rarely occur in the general population. ${ }^{89}$

The unexpected findings of Pouplard have attracted world-wide interest and we know of several groups who are attempting to replicate these results. In view of its

${ }^{3}$ Spark RF, Baker R, Bienfang DC, Bergland R. size and hypersecretion. JAMA 1982; 247:311-6.

Bromocriptine in management of large pituitary tumo

Long term treatment of acromegaly with bromocriptine. Br Med J 1977; 1:875-8.

Accepted 10 October 1984

Prolactin cell autoantibodies and

Sir: Alzheimer's disease is the commonest based on a history of gradual global intellectual deterioration, and the exclusion of dementia. To be complete the latter requires an extensive, and expensive, series of investigations including CT brain scan. ${ }^{2}$ The search for readily identifiable markers cut this process and facilitate earlier and more accurate diagnosis has so far beerad The possibility that there may be immunological markers for Alzheimer' disease would be of clinical and theoreticab To date the association beo tween Alzheimer's disease and certain his tioned $^{3}$ and the finding of abnormally raised levels of immunoglobulins in cognicated. ${ }^{5}$ However, Pouplard et $a l^{6}$ using an indirect immunofluorescence test on cryosary (2-3 hours after death), recently eported that 26 of 27 cases of Alzheimer's , all 11 cases of Down's yndrome with dementia (where the neuropathological changes parallel those of

References

McGregor AM, Scanlon MF, Hall R, Hall K. Effects of bromocriptine on pituitary tumour size. $\mathrm{Br}$ Med J 1979;i: 700-3.

${ }^{2}$ Barrow DL, Tindall GT, Kovacs K, Thorner MO, Horvath E, Hoffman JC. Clinical and pathological effects of bromocriptine on prolactin secreting and other pituitary tumours. J Neurosurg 1984;60:1-7. 